\title{
MITIGATION OF SALINITY STRESS IN SOYBEAN USING ORGANIC AMENDMENTS
}

\author{
J. Ferdous ${ }^{1 *}$, M. A. Mannan', M. M. Haque', M. S. Alam ${ }^{3}$ and S. Talukder ${ }^{4}$ \\ ${ }^{1}$ Bangladesh Jute Research Institute, Dhaka \\ ${ }^{2}$ Department of Agronomy, Bangabandhu Sheikh Mujibur Rahman Agricultural University, \\ Gazipur-1706, Bangladesh \\ ${ }^{3}$ Department of Soil Science, Bangabandhu Sheikh Mujibur Rahman Agricultural University, \\ Gazipur-1706, Bangladesh \\ ${ }^{*}$ Corresponding author, E-mail: tanny.jannat92@gmail.com
}

(Received: 5 December 2017, Accepted: 25 February 2018)

Keywords: Salinity stress, biochar, organic amendments and mitigation

\begin{abstract}
A pot experiment was carried out in semi-controlled condition at the Department of Agronomy, Bangabandhu Sheikh Mujibur Rahman Agricultural University (BSMRAU), Gazipur from November 2015 to March 2016 to assess the effect of organic amendments to mitigate salinity stress in Soybean var. BARI soybean 5. Two types of organic amendments i) water hyacinth compost and ii) rice husk biochar were mixed in soil @ 5 and $10 \mathrm{t} \mathrm{ha}^{-1}$ of both. Saline solution was prepared by adding tap water in seawater to make 5 and $10 \mathrm{dS} \mathrm{m}^{-1}$ salinity respectively. Plants were irrigated with the salt solution from $14^{\text {th }}$ day after sowing (DAS) to maturity and the control plants were irrigated with tap water. Data on different parameters like plant height, leaf, stem, root dry matter and yield contributing parameters were recorded at harvest. Experimental results revealed that salinity decreased plant height, dry weight of leaf, stem and root as well as yield of soybean plant ${ }^{-1}$. Application of water hyacinth compost and rice husk biochar had positive effects on mitigating the negative effects of salinity stress on all those parameters studied. However, rice husk biochar at the rate of $5 \mathrm{t} \mathrm{ha}^{-1}$ showed best result to mitigate salinity stress at low salinity $\left(5 \mathrm{dSmdS} \mathrm{m}{ }^{-1}\right.$ condition.
\end{abstract}

\section{Introduction}

Soybean (Glycine max. L) is one of the most important oilseeds crop of the world due to its high food value. It contains about 36-40\% protein, $18-20 \%$ oil, $30 \%$ carbohydrate, $7.3 \%$ sugar and $9.3 \%$ dietary fiber and also unsaturated fatty acids, minerals like $\mathrm{Ca}$ and $\mathrm{P}$ including vitamin A, B, C and vitamin D. In Bangladesh, the total cultivated area under soybean cultivation is 41440 hectares which produces 65883 tons of oil per year (FAO, 2013). The cultivation of soybean is increasing in Bangladesh mostly due to its increasing demand in the poultry sector. Agricultural productivity is severely affected by soil salinity and the damaging effect of salt accumulation in agricultural soils has become an important environmental concern all over the world. Accumulation of excess $\mathrm{Na}$ and $\mathrm{Cl}$ in plant body causes ionic imbalances that may impair the selectivity of root membranes and induce potassium deficiency (Gadallah, 1999). The deficiency of $\mathrm{K}$ initially leads to chlorosis and then causes necrosis (Gopal and Dube, 2003).Excess soluble salts reduce yields by impairing germination, or creating osmotic gradients which interfere with the uptake of essential nutrients by plants (Bernstein, 1975; Stamatiadis et al., 1999; Tanji, 1990).

Out of 2.86 million hectares of coastal and offshore lands, about 1.056 million hectares are affected by varying degrees of salinity (SRDI, 2010). Reclamation of saline soil is difficult. 
Therefore, alternative ways may be adopted like mitigation of salinity using different organic amendments. There are evidences that soil amendments with various organic substances such as farmyard manure, poultry manure and mulch can be used for the reduction of toxic effects of salinity in various plant species (Idrees et al., 2004; Abou El-Magd et al., 2008; Leithy et al., 2010; Raafat and Thawrat, 2011). Water hyacinth-compost is a dark, crumbly, earthy-smelling mixture that consists mostly of decayed organic matter. Composts are widely used as sources of nutrients and organic matter. The beneficial influence of compost on soil physical and chemical properties has been well documented (Debosz et al., 2002; Lynch et al., 2005; Tejada et al., 2006; Wanas and Omran, 2006). Biochar is pyrolysed organic material intended for use as a soil amendment to sustainably sequester $\mathrm{C}$ and concurrently improve soil function, while avoiding any adverse effects, on both the short and long terms (Verheijen et al., 2009). Biochar enhanced soil water-holding capacity (Asai et al., 2009; Laird et al., 2010); improved soil water permeability (Asai et al., 2009); improved saturated hydraulic conductivity (SHC) (Asai et al., 2009); reduced soil strength (Chan et al., 2007, 2008) and modification in soil bulk density ( $\mathrm{pb}$ ) (Laird et al., 2010). Therefore, both water hyacinth-compost and biochar may reduce the harmful effect of salinity on crop productivity. However, scarce information is available on the effect of the organic amendments on mitigation of salinity on soybean. Therefore, this experiment was carried out to analyze the effect of water hyacinth-compost and biochar on growth performance of soybean under saline conditions.

\section{Materials and Methods}

The pot experiment was carried out in the Department of Agronomy, Bangabandhu Sheikh Mujibur Rahman Agricultural University, Gazipur from November 2015 to March 2016 to investigate the effect of organic amendments to mitigate negative effects of salinity stress on different parameters of soybean var. BARI soybean 5 . The soil was a sandy loam with $\mathrm{pH} 6.93$, total $\mathrm{N}=0.07 \%$, available $\mathrm{P}=0.08 \mathrm{mg} 100 \mathrm{~g}^{-1}$ dry soil, exchangeable $\mathrm{K}=0.79 \mathrm{cmol}_{\mathrm{c}} \mathrm{kg}^{-1} \mathrm{dry}$ soil, available $\mathrm{S}=10 \mathrm{ppm}$, organic carbon $=0.61 \%, \mathrm{CEC}=13.05 \mathrm{cmol}_{\mathrm{c}} \mathrm{kg}^{-1}$ dry soil and $\mathrm{EC}=$ $0.4 \mathrm{dS} \mathrm{m}^{-1}$. The experiment was consisted of 15 treatments as: $\mathrm{T}_{0}=\mathrm{Control}$ (without organic amendments and seawater ), ), $\mathrm{T}_{1}=5 \mathrm{dSm}^{-1}$ seawater, $\mathrm{T}_{2}=10 \mathrm{dS} \mathrm{m}^{-1}$ seawater, $\mathrm{T} 3=$ Compost @ $5 \mathrm{t}$ $\mathrm{ha}^{-1}, \mathrm{~T}_{4}=$ Compost @ $10 \mathrm{tha}^{-1}, \mathrm{~T}_{5}=$ Compost @ $5 \mathrm{t} \mathrm{ha}^{-1}$ with $5 \mathrm{dSm}^{-1}$ sea water, $\mathrm{dS} \mathrm{m}^{-1}$ seawater, $\mathrm{T}_{6}=$ Compost @ $10 \mathrm{t} \mathrm{ha}^{-1}$ with $5 \mathrm{dS} \mathrm{m}{ }^{-1}$ seawater, $\mathrm{T}_{7}=$ Compost @ $5 \mathrm{t} \mathrm{ha}^{-1}$ with $10 \mathrm{dSm}^{-1}$ sea water with $10 \mathrm{dS} \mathrm{m}^{-1}$ seawater, $\mathrm{T}_{8}=$ Compost @ $10 \mathrm{t} \mathrm{ha}^{-1}$ with $10 \mathrm{dSm}^{-1}$ sea- water, with $10 \mathrm{dS} \mathrm{m}^{-}$ ${ }^{1}$ seawater, $\mathrm{T}_{9}=$ Biochar@ $5 \mathrm{t} \mathrm{ha}^{-1}, \mathrm{~T}_{10}=$ Biochar @ $10 \mathrm{t} \mathrm{ha}{ }^{-1}, \mathrm{~T}_{11}=$ Biochar @ $5 \mathrm{t} \mathrm{ha}^{-1}$ with 5 $\mathrm{dSm}{ }^{-1}$ seawater, $\mathrm{dS} \mathrm{m}{ }^{-1}$ seawater, $\mathrm{T}_{12}=$ Biochar @ $10 \mathrm{t} \mathrm{ha}^{-1}$ with $5 \mathrm{dSm}^{-1}$ seawater, $\mathrm{dS} \mathrm{m}^{-1}$ seawater, $\mathrm{T}_{13}=$ Biochar @ $5 \mathrm{t} \mathrm{ha}^{-1}$ with $10 \mathrm{dSm}^{-1}$ seawater,with $10 \mathrm{dS} \mathrm{m}^{-1}$ seawater, $\mathrm{T}_{14}=$ Biochar @ $10 \mathrm{t} \mathrm{ha}^{-}$

1 with $10 \mathrm{dSm}^{-1}$ seawater.with $10 \mathrm{dS} \mathrm{m}^{-1}$ seawater. Saline solution was prepared by adding tap water in sea- water to make 5 and $100 \mathrm{mM}$ salinity, respectively. Plants were irrigated with 5 $\mathrm{dSm}^{-1} \mathrm{dS} \mathrm{m}^{-1}$ and $10 \mathrm{dSm}^{-1} \mathrm{dS} \mathrm{m}^{-1}$ salt solution from 14 days after sowing (DAS) to maturity and control plants were irrigated with tap water. The organic amendments were mixed with pot soil. The experiment was laid out in a completely randomized design (CRD) with three replications. Data on different parameters like plant height, dry matter production in different plant parts, yield and yield contributing charecteristieswere recorded at harvest. The recorded data were statistically analyzed by "CROPSTAT 7.2" software to examine the significant variations in the results due to different treatments. The treatment means were compared by Least Significance Difference (LSD) test at 5\% level of significance (Gomez and Gomez, 1984).

\section{Results and Discussion}

\section{Plant height}

Soil salinity caused a significant effect in plant height of soybean. At control, plant height was found $17.3 \mathrm{~cm}$ but it was $17.7 \mathrm{~cm}$ and $15.0 \mathrm{~cm}$ under 5 and $10 \mathrm{dSm}^{-1}$ salinity levels, respectively 
(Fig. 1). It was observed that plant height increased at $5 \mathrm{dSm}^{-1}$ than control, because lower level of salinity might have acted as nutrient of plant growth. At $10 \mathrm{dSm}^{-1}$ seawater treatment caused a drastic decreased in plant height and it indicates that high level of salinity was harmful for plant height. Organic amendments significantly increased the plant height of soybean under both control and salt stress conditions. At control condition, highest plant height $(23.0 \mathrm{~cm})$ was found when soil was treated with biochar @ $10 \mathrm{t} \mathrm{ha}^{-1}$ and the lowest height $(19.3 \mathrm{~cm})$ with water hyacinth compost was added in the soil @ $10 \mathrm{t} \mathrm{ha}^{-1}$. At $5 \mathrm{dSm}^{-1}$ salinity stress highest plant height $(22.0 \mathrm{~cm})$ was recorded when soil was treated with water hyacinth compost @ $10 \mathrm{t} \mathrm{ha}^{-1}$ and the lowest height $(19.7 \mathrm{~cm})$ when soil was treated with compost @ $5 \mathrm{t} \mathrm{ha}^{-1}$ but similar plant height also recorded from biochar amendment @ $10 \mathrm{t} \mathrm{ha}^{-1}$. On the other hand, under $10 \mathrm{dSm}^{-1}$ salinity stress the tallest plant $(20 \mathrm{~cm})$ was found when soil was treated with biochar @ $10 \mathrm{t} \mathrm{ha}^{-1}$ and the shortest plant $(16.7 \mathrm{~cm})$ from compost amendment @ $5 \mathrm{t} \mathrm{ha}^{-1}$. Results indicated that plant height decreased with increasing salinity level and varied with different organic amendments.

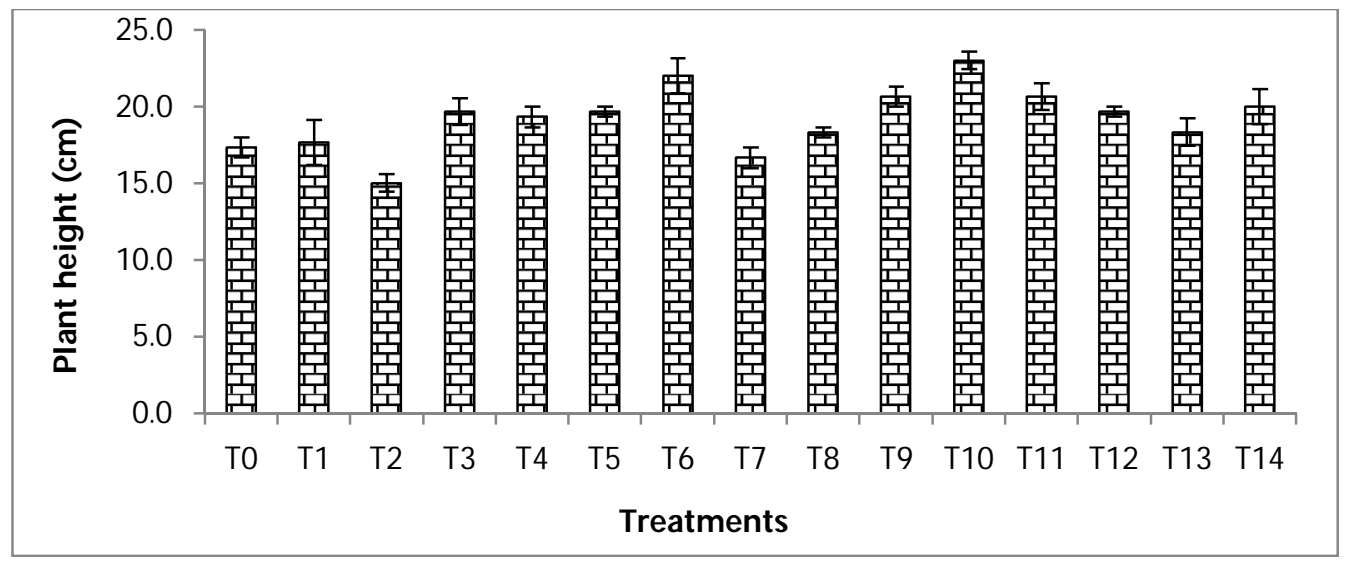

Fig. 1. Effect of organic amendments on plant height of soybean under saline conditions. Bars indicate SE $( \pm)$

$\mathrm{T}_{0}=$ Control (without organic amendments and sea water), $\mathrm{T}_{1}=5 \mathrm{dSm}^{-1} \mathrm{mM}$ seawater, $\mathrm{T}_{2}=10 \mathrm{dSm}^{-1}$ seawater, $\mathrm{T}_{3}=$ Compost @ $5 \mathrm{t} \mathrm{ha}^{-1}, \mathrm{~T}_{4}=$ Compost @ $10 \mathrm{t} \mathrm{ha}^{-1}, \mathrm{~T}_{5}=$ Compost @ $5 \mathrm{t} \mathrm{ha}^{-1}$ with $5 \mathrm{dSm}^{-1}$ seawater, $\mathrm{T}_{6}=$ Compost @ $10 \mathrm{t} \mathrm{ha}^{-1}$ with $5 \mathrm{dSm}^{-1}$ sea- water, $\mathrm{T}_{7}=$ Compost @ $5 \mathrm{tha}^{-1}$ with $10 \mathrm{dSm}^{-1}$ sea- water, $\mathrm{T}_{8}=$ Compost @ $10 \mathrm{t} \mathrm{ha}^{-1}$ with $10 \mathrm{dSm}^{-1}$ sea- water, $\mathrm{T}_{9}=$ Biochar @ $5 \mathrm{t} \mathrm{ha}^{-1}, \mathrm{~T}_{10}=$ Biochar $@ 10 \mathrm{t} \mathrm{ha}^{-1}, \mathrm{~T}_{11}=$ Biochar @ $5 \mathrm{t} \mathrm{ha}^{-1}$ with $5 \mathrm{dSm}^{-1}$ sea water, $\mathrm{T}_{12}=$ Biochar @ $10 \mathrm{t} \mathrm{ha}^{-1}$ with $5 \mathrm{dSm}^{-1}$ sea- water, $\mathrm{T}_{13}=$ Biochar @ $5 \mathrm{t} \mathrm{ha}^{-1}$ with $10 \mathrm{dSm}^{-1}$ sea-water, $\mathrm{T}_{14}=$ Biochar @ $10 \mathrm{tha}^{-1}$ with $10 \mathrm{dSm}^{-1}$ sea-water

\section{Dry matter production in different plant parts \\ Leaf dry matter}

Leaf dry matter weight plant $^{-1}$ was reduced due to salinity (Fig. 2). The lowest leaf dry mass (1.97 $\mathrm{g} \mathrm{plant}^{-1}$ ) was recorded at $10 \mathrm{dSm}^{-1}$ salt condition. Organic amendment significantly increased leaf dry matter of soybean under control and saline conditions. Highest leaf dry matter (7.11 g plant $\mathrm{t}^{-1}$ ) was observed when biochar was added @ $5 \mathrm{t} \mathrm{ha}^{-1}$ and it was $6.32 \mathrm{~g} \mathrm{plant}^{-1}$ when compost was added @ $10 \mathrm{t} \mathrm{ha}^{-1}$ under control condition. At $5 \mathrm{dSm}^{-1}$ salinity condition, highest leaf dry matter $\left(4.57 \mathrm{~g} \mathrm{plant}^{-1}\right)$ was obtained from compost @ $5 \mathrm{t} \mathrm{ha}^{-1}$ and lowest $\left(3.9 \mathrm{~g} \mathrm{plant}^{-1}\right)$ at compost @ $10 \mathrm{tha}^{-1}$. At $10 \mathrm{dSm}^{-1}$ saline condition, highest leaf dry matter $\left(2.69 \mathrm{~g} \mathrm{plant}^{-1}\right)$ was obtained when soil was treated with biochar @ $10 \mathrm{t} \mathrm{ha}^{-1}$ and it was lowest $\left(2.43 \mathrm{~g} \mathrm{plant}^{-1}\right)$ when compost added @ $10 \mathrm{t} \mathrm{ha}^{-1}$. Dry weight of stem, leaves and whole plant showed approximately decrease with salinity observed by Hussein et al. (2007). 


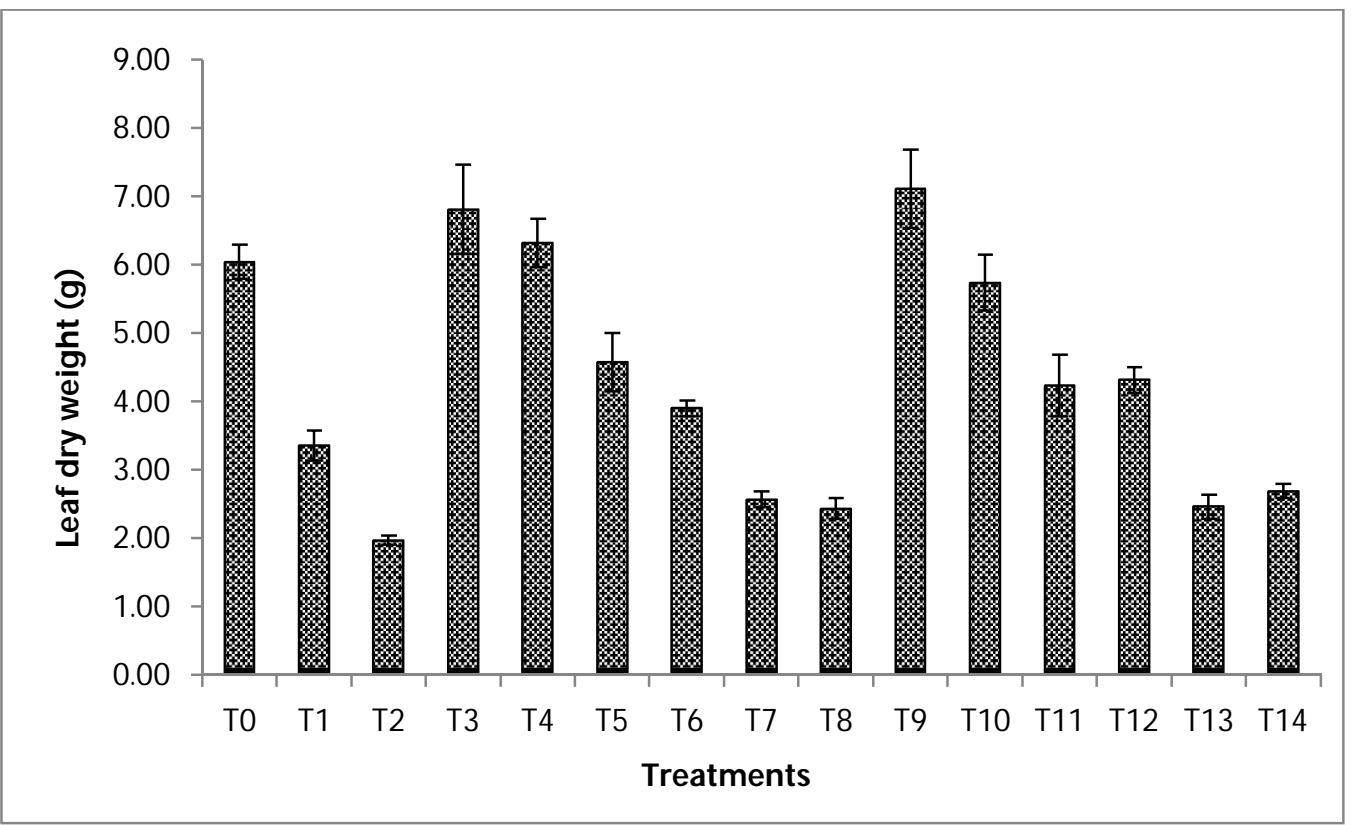

Fig. 2. Effect of organic amendments on leaf dry weight of soybean under saline conditions. Bars indicate SE $( \pm)$.

$\mathrm{T}_{0}=$ Control(without organic amendments and sea water), $\mathrm{T}_{1}=50 \mathrm{mM}$ sea water $\mathrm{T}_{2}=100 \mathrm{mM}$ sea water, $\mathrm{T}_{3}$ $=$ Compost @ $5 \mathrm{t} / \mathrm{ha}, \mathrm{T}_{4}=$ Compost @ $10 \mathrm{t} / \mathrm{ha}, \mathrm{T}_{5}=$ Compost $@ 5 \mathrm{t} / \mathrm{ha}$ with $50 \mathrm{mM}$ sea water, $\mathrm{T}_{6}=$ Compost @ $10 \mathrm{t} / \mathrm{ha}$ with $50 \mathrm{mM}$ sea water, T7= Compost @ $5 \mathrm{t} / \mathrm{ha}$ with $100 \mathrm{mM}$ sea water, $\mathrm{T} 8=$ Compost @ $10 \mathrm{t} / \mathrm{ha}$ with 100mM sea water, $\mathrm{T}_{9}=$ Biochar @ $5 \mathrm{t} / \mathrm{ha}, \mathrm{T}_{10}=$ Biochar @ $10 \mathrm{t} / \mathrm{ha}, \mathrm{T}_{11}=$ Biochar @ $5 \mathrm{t} / \mathrm{ha}$ with 50mM sea water, $\mathrm{T}_{12}=$ Biochar @10 t/ha with 50mM sea water, $\mathrm{T}_{13}=$ Biochar @ $5 \mathrm{t} / \mathrm{ha}$ with 100mM sea water, $\mathrm{T}_{14}=$ Biochar @ 10 t/ha with $100 \mathrm{mM}$ sea water

\section{Stem dry matter}

Stem dry matter plant ${ }^{-1}$ of soybean was reduced due to salinity and reduction was higher with increasing salinity levels (Fig. 3). The lowest stem dry mass $\left(2.02 \mathrm{~g} \mathrm{plant}^{-1}\right)$ was recorded at 100 $\mathrm{mM}$ salt condition. At every case of compost and biochar treatment the stem dry mass was increasing compared to normal condition. Highest stem dry matter $\left(6.18 \mathrm{~g} \mathrm{plant}^{-1}\right)$ was observed when biochar was added @ $5 \mathrm{t} \mathrm{ha}^{-1}$ and the lowest value $\left(5.40 \mathrm{~g} \mathrm{plant}^{-1}\right)$ when compost was added $5 \mathrm{t} \mathrm{ha}^{-1}$ under control condition. At $5 \mathrm{dSm}^{-1}$ salinity condition, highest stem dry matter (4.70 $\mathrm{g}_{\text {plant }}{ }^{-1}$ ) was obtained from biochar @ $5 \mathrm{t} \mathrm{ha}^{-1}$ and the lowest stem dry matter $(4.21 \mathrm{~g}$ plant $\left.^{-1}\right)$ at $5 \mathrm{t} \mathrm{ha}^{-1}$. Under $10 \mathrm{dSm}^{-1}$ saline condition highest stem dry matter $\left(2.69 \mathrm{~g} \mathrm{plant}^{-1}\right)$ was obtained when soil was treated with compost @ $5 \mathrm{t} \mathrm{ha}^{-1}$ and lowest $\left(2.28 \mathrm{~g} \mathrm{plant}^{-1}\right)$ when biochar was added $10 \mathrm{t} \mathrm{ha}^{-1}$. Reduction in stem dry matter due to salinity as compared to control was reported earlier by Karim et al. (1992) in triticale. 


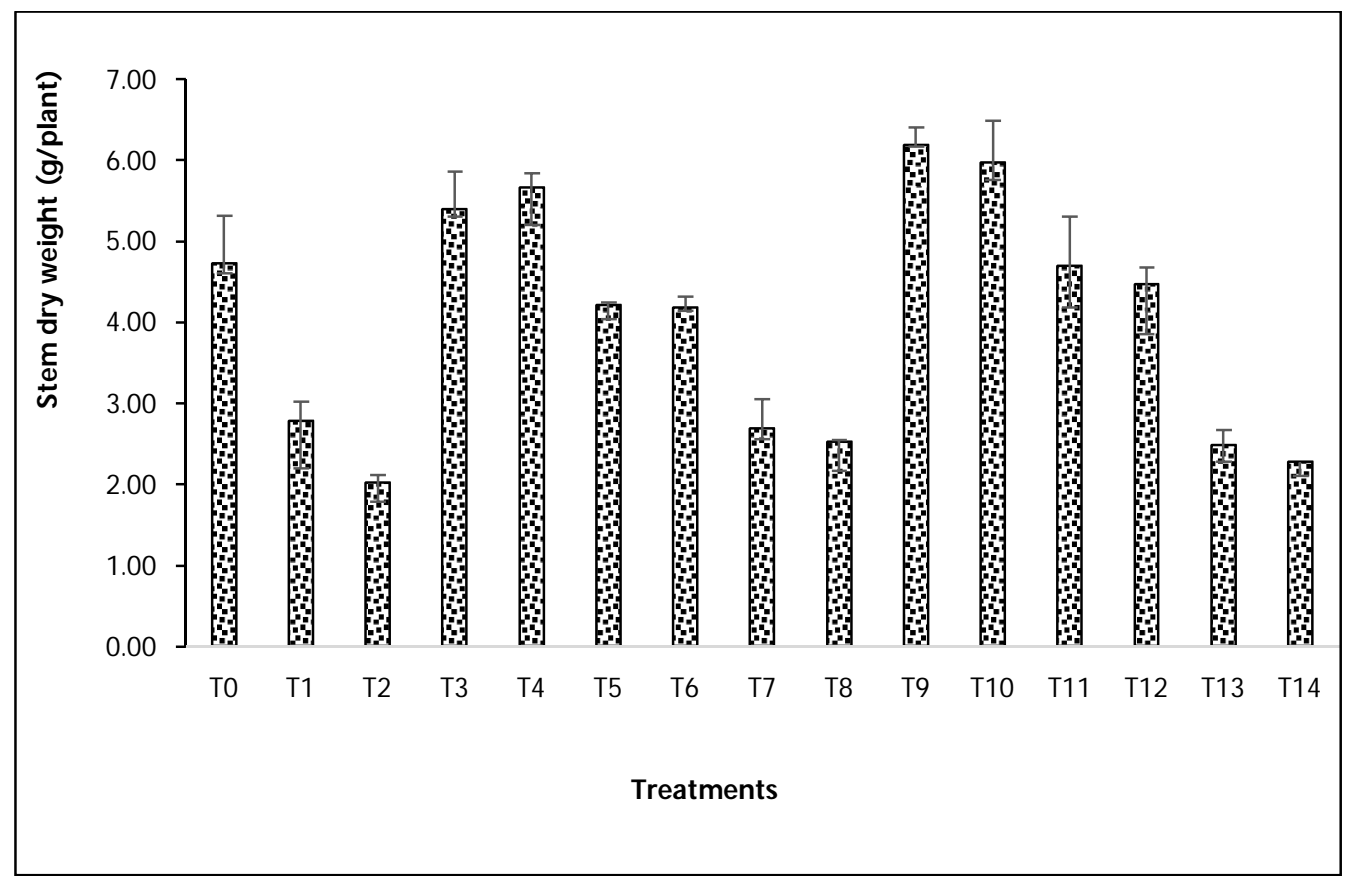

Fig. 3. Effect of organic amendments on stem dry weight of soybean under saline conditions. Bars indicate SE $( \pm)$.

$\mathrm{T}_{0}=$ Control (without organic amendments and sea water), $\mathrm{T}_{1}=50 \mathrm{mM}$ sea water $\mathrm{T}_{2}=100 \mathrm{mM}$ sea water, $\mathrm{T}_{3}$ = Compost @ $5 \mathrm{t} \mathrm{ha}^{-1}, \mathrm{~T}_{4}=$ Compost @ $10 \mathrm{t} \mathrm{ha}^{-1}, \mathrm{~T}_{5}=$ Compost $@ 5 \mathrm{t} \mathrm{ha}^{-1}$ with $50 \mathrm{mM}$ sea water, $\mathrm{T}_{6}=$ Compost @ $10 \mathrm{t} \mathrm{ha}^{-1}$ with $50 \mathrm{mM}$ sea water, $\mathrm{T}_{7}=$ Compost @ $5 \mathrm{t} \mathrm{ha}^{-1}$ with $100 \mathrm{mM}$ sea water, $\mathrm{T}_{8}=$ Compost @ $10 \mathrm{t} \mathrm{ha}^{-1}$ with 100mM sea water, $\mathrm{T}_{9}=$ Biochar @ $5 \mathrm{t} \mathrm{ha}^{-1}, \mathrm{~T}_{10}=$ Biochar @ $10 \mathrm{tha}^{-1}, \mathrm{~T}_{11}=$ Biochar @ $5 \mathrm{t}$ ha ${ }^{-1}$ with 50mM sea water, $\mathrm{T}_{12}=$ Biochar @ $10 \mathrm{t} \mathrm{ha}^{-1}$ with $50 \mathrm{mM}$ sea water, $\mathrm{T}_{13}=$ Biochar @ $5 \mathrm{t} \mathrm{ha}^{-1}$ with $100 \mathrm{mM}$ sea water, $\mathrm{T}_{14}=$ Biochar @ $10 \mathrm{t} \mathrm{ha}^{-1}$ with $100 \mathrm{mM}$ sea water

\section{Root dry matter}

Experimental results revealed that root dry matter was significantly affected by salinity (Fig. 4). The lowest root dry mass $\left(0.50 \mathrm{~g} \mathrm{plant}^{-1}\right)$ was recorded at $10 \mathrm{dSm}^{-1}$ salt condition. Under control condition, highest root dry matter $\left(2.53 \mathrm{~g} \mathrm{plant}^{-1}\right)$ was recorded with adding biochar @ $5 \mathrm{t} \mathrm{ha}^{-1}$ and the lowest $\left(2.17 \mathrm{~g}\right.$ plant $\left.^{-1}\right)$ with @ $10 \mathrm{t} \mathrm{ha}^{-1}$. At $5 \mathrm{dSm}^{-1}$ salinity condition, highest root dry matter $\left(1.70 \mathrm{~g}\right.$ plant $\left.{ }^{-1}\right)$ was obtained with biochar @ $5 \mathrm{t} \mathrm{ha}^{-1}$ and lowest $\left(1.37 \mathrm{~g} \mathrm{plant}^{-1}\right)$ with compost@5 tha ${ }^{-1}$. At $10 \mathrm{dSm}^{-1}$ saline condition, highest root dry matter $\left(0.90 \mathrm{~g} \mathrm{plant}^{-1}\right)$ was obtained when soil was treated with compost @ $5 \mathrm{t} \mathrm{ha}^{-1}$ and lowest $\left(0.77 \mathrm{~g} \mathrm{plant}^{-1}\right)$ with biochar as well as compost both @ $10 \mathrm{t} \mathrm{ha}^{-1}$. Salinity induced root mass reduction was reported earlier by Raptan et al. (2001) and Sultana et al. (2007) in mungbean. 


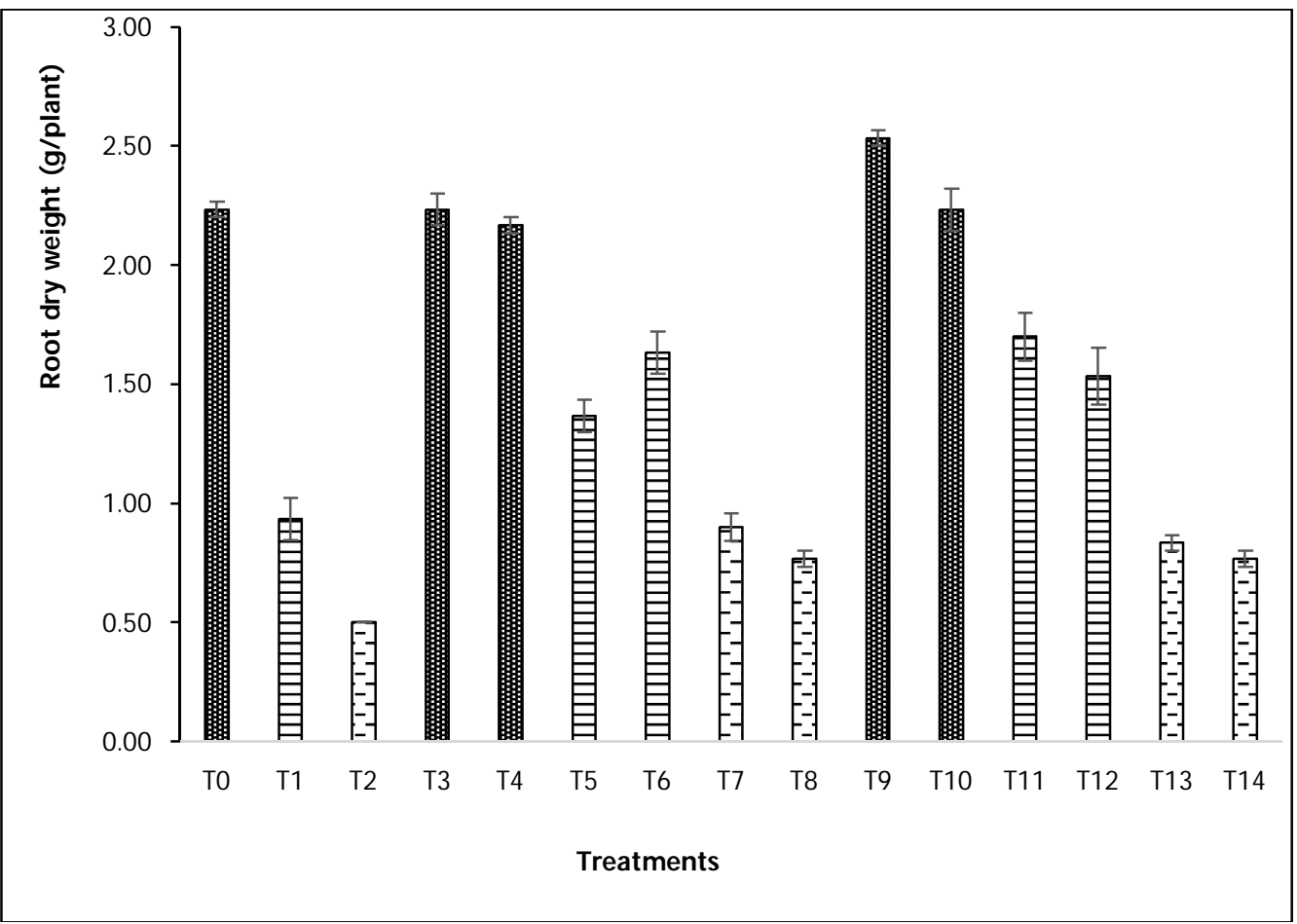

Fig. 4. Effect of organic amendments on root dry weight of soybean under saline conditions. Bars indicate SE $( \pm)$.

$\mathrm{T}_{0}=$ Control (without organic amendments and sea water), $\mathrm{T}_{1}=50 \mathrm{mM}$ sea water $\mathrm{T}_{2}=100 \mathrm{mM}$ sea water, $\mathrm{T}_{3}$ =Compost @ $5 \mathrm{t} \mathrm{ha}^{-1}, \mathrm{~T}_{4}=$ Compost @ $10 \mathrm{t} \mathrm{ha}^{-1}, \mathrm{~T}_{5}=$ Compost $@ 5 \mathrm{t} \mathrm{ha}^{-1}$ with $50 \mathrm{mM}$ sea water, $\mathrm{T}_{6}=$ Compost @ $10 \mathrm{t} \mathrm{ha}^{-1}$ with $50 \mathrm{mM}$ sea water, $\mathrm{T}_{7}=$ Compost @ $5 \mathrm{t} \mathrm{ha}^{-1}$ with $100 \mathrm{mM}$ sea water, $\mathrm{T}_{8}=$ Compost @ $10 \mathrm{t} \mathrm{ha}^{-1}$ with 100mM sea water, $\mathrm{T}_{9}=$ Biochar @ $5 \mathrm{t} \mathrm{ha}^{-1}, \mathrm{~T}_{10}=$ Biochar @ $10 \mathrm{tha}^{-1}, \mathrm{~T}_{11}=$ Biochar @ $5 \mathrm{t}$ ha $^{-1}$ with $50 \mathrm{mM}$ sea water, $\mathrm{T}_{12}=$ Biochar @ $10 \mathrm{t} \mathrm{ha}^{-1}$ with $50 \mathrm{mM}$ sea water, $\mathrm{T}_{13}=$ Biochar @ $5 \mathrm{t} \mathrm{ha}^{-1}$ with $100 \mathrm{mM}$ sea water, $\mathrm{T}_{14}=$ Biochar @ $10 \mathrm{tha}^{-1}$ with $100 \mathrm{mM}$ sea water

\section{Shoot dry matter}

The shoot dry weight is defined as the sum total of leaf, stem, and petiole dry weight. Shoot dry matter was negatively affected by increasing salinity level (Fig. 5). The lowest shoot dry mass (3.99 $\mathrm{g} \mathrm{plant}^{-1}$ ) was recorded at $10 \mathrm{dSm}^{-1}$ salt condition. Organic amendment significantly increased shoot dry matter of soybean under control and saline conditions. Highest shoot dry matter (13.30 $\left.\mathrm{g} \mathrm{plant}^{-1}\right)$ was recorded when biochar was added @ $5 / \mathrm{ha}^{-1}$ and it was $11.71 \mathrm{~g}$ plant $^{-1}$ when biochar was added @ $10 \mathrm{t} \mathrm{ha}^{-1}$ under control condition. At $5 \mathrm{dSm}^{-1}$ salinity condition highest shoot dry matter $\left(8.93 \mathrm{~g} \mathrm{plant}^{-1}\right)$ was obtained adding biochar@ $5 \mathrm{t} \mathrm{ha}^{-1}$ and lowest (8.08 $\left.\mathrm{g} \mathrm{plant}^{-1}\right)$ adding compost @ $10 \mathrm{t} \mathrm{ha}^{-1}$. Under $10 \mathrm{dSm}^{-1}$ saline condition, highest shoot dry matter (5.26 g plant $\left.{ }^{-1}\right)$ was recorded with compost @ $5 \mathrm{t} \mathrm{ha}^{-1}$ and the lowest $(4.97 \mathrm{~g}$ plant $^{-1}$ ) with biochar as well as compost both @ $10 \mathrm{t} \mathrm{ha}^{-1}$.Reduction in shoot dry weight due to salinity as compared to control was reported by Sultana et al. (2007) in six mungbean varieties. Increasing salinity level resulted in significant reductions of shoot biomass, root length and volume. At each salinity level, incorporation of biochar increased shoot biomass, root length and volume observed by Akhtar et al. (2015). 


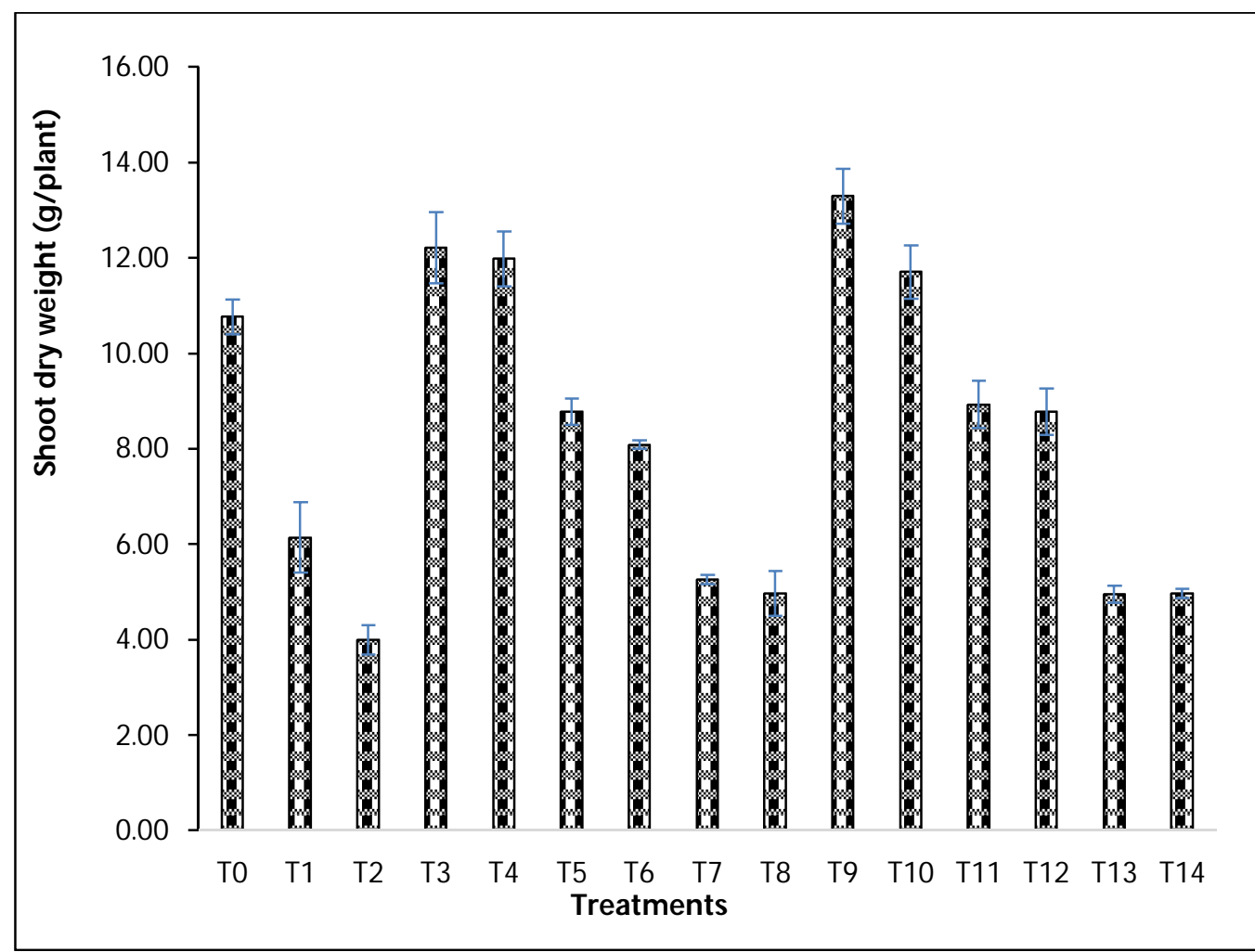

Fig. 5. Effect of organic amendments on shoot dry weight of soybean under saline conditions. Bars indicate SE $( \pm)$.

$T_{0}=$ Control (without organic amendments and sea water), $T_{1}=50 \mathrm{mM}$ sea water $T_{2}=100 \mathrm{mM}$ sea water, $T_{3}$ =Compost @ $5 \mathrm{t} \mathrm{ha}^{-1}, \mathrm{~T}_{4}=$ Compost @ $10 \mathrm{t} \mathrm{ha}^{-1}, \mathrm{~T}_{5}=$ Compost $@ 5 \mathrm{t} \mathrm{ha}^{-1}$ with 50mM sea water, $\mathrm{T}_{6}=$ Compost @ $10 \mathrm{tha}^{-1}$ with $50 \mathrm{mM}$ sea water, T7= Compost @ $5 \mathrm{t} \mathrm{ha}^{-1}$ with $100 \mathrm{mM}$ sea water, $\mathrm{T}_{8}=$ Compost @10 t ha $a^{-1}$ with 100mM sea water, $\mathrm{T}_{9}=$ Biochar@ @ $5 \mathrm{tha}^{-1}, \mathrm{~T}_{10}=$ Biochar@ $10 \mathrm{tha}^{-1}, \mathrm{~T}_{11}=$ Biochar@ $5 \mathrm{t}$ ha ${ }^{-1}$ with 50mM sea water, $\mathrm{T}_{12}=$ Biochar @ $10 \mathrm{t} \mathrm{ha}^{-1}$ with 50mM sea water, $\mathrm{T}_{13}=$ Biochar @ $5 \mathrm{t} \mathrm{ha}^{-1}$ with $100 \mathrm{mM}$ sea water, $\mathrm{T}_{14}=$ Biochar @ $10 \mathrm{tha}^{-1}$ with $100 \mathrm{mM}$ sea water

\section{Total dry matter}

Reduction in total dry matter production under saline condition and the positive effect of organic amendment on total dry matter production are presented in Fig. 6 . Both $5 \mathrm{dSm}^{-1}$ and 10 $\mathrm{dSm}^{-1}$ salinity affect significantly on the total dry matter production in soybean plant. Total dry matter of plant was decreased with the increase of soil salinity and the highest (4.36 g plant $\left.{ }^{-1}\right)$ reduction occurred at $10 \mathrm{dSm}^{-1}$ salinity level. Organic amendment significantly increased total dry matter of soybean under control and saline conditions. Highest total dry matter $(15.66 \mathrm{~g}$ plant $^{-1}$ ) was recorded with adding biochar @ $5 \mathrm{t} \mathrm{ha}^{-1}$ and the lowest $\left(13.94 \mathrm{~g} \mathrm{plant}^{-1}\right)$ with biochar @ $10 \mathrm{t} \mathrm{ha}^{-1}$ under control condition. At $5 \mathrm{dS} \mathrm{m}^{-1} \mathrm{mM}$ salinity condition, highest total dry matter (10.53 $\left.\mathrm{g} \mathrm{plant}^{-1}\right)$ was obtained from biochar @ $5 \mathrm{t} \mathrm{ha}^{-1}$ and the lowest $\left(9.72 \mathrm{~g} \mathrm{plant}^{-1}\right)$ from compost @ $10 \mathrm{t} \mathrm{ha}^{-1}$. Under $10 \mathrm{dSm}^{-1}$ saline condition, highest total dry matter $\left(6.16 \mathrm{~g} \mathrm{plant}^{-1}\right)$ was obtained when soil was treated with compost @ $5 \mathrm{t} \mathrm{ha}^{-1}$ and lowest $\left(5.46 \mathrm{~g} \mathrm{plant}^{-1}\right)$ when biochar was added in the soil @ $5 \mathrm{t} \mathrm{ha}^{-1}$. Reduction in total dry matter production under salinity was also reported Raptan et al. (2001) in mungbean. 


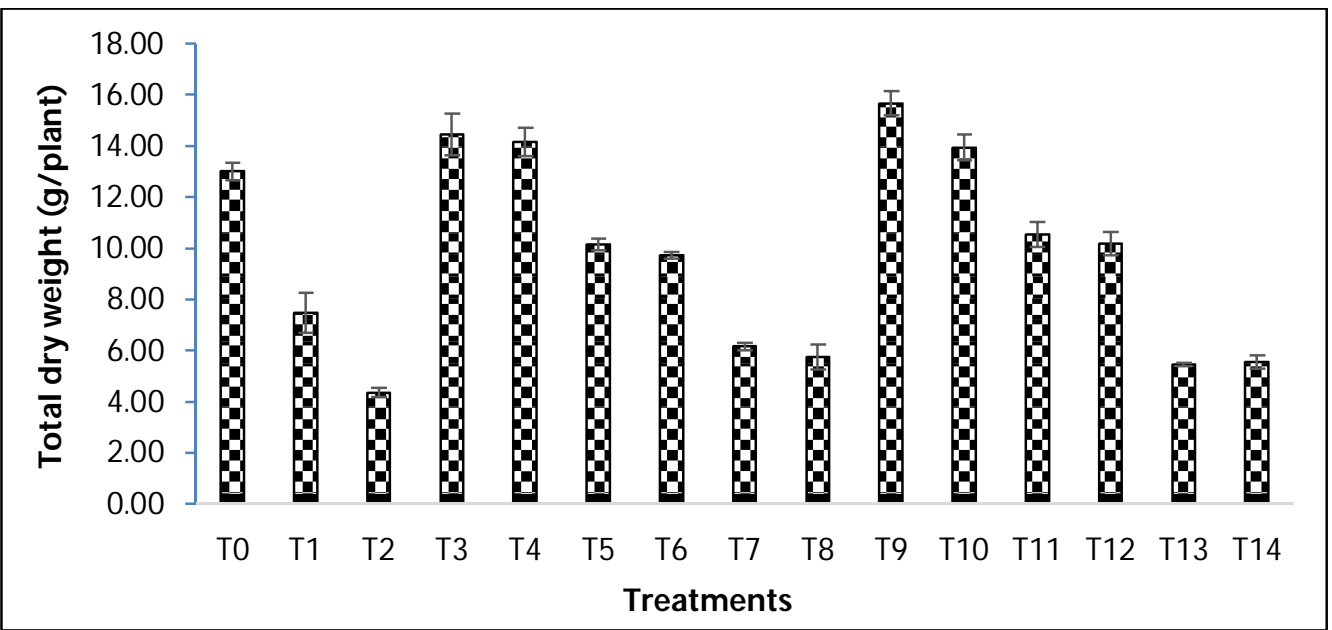

Fig. 6. Effect of organic amendments on total dry matter weight of soybean under saline conditions. Bars indicate SE $( \pm)$.

$\mathrm{T}_{0}=$ Control (without organic amendments and sea water), $\mathrm{T}_{1}=50 \mathrm{mM}$ sea water $\mathrm{T}_{2}=100 \mathrm{mM}$ sea water, $\mathrm{T}_{3}$ =Compost @ $5 \mathrm{t} \mathrm{ha}^{-1}, \mathrm{~T}_{4}=$ Compost @ $10 \mathrm{t} \mathrm{ha}^{-1}, \mathrm{~T}_{5}=$ Compost $@ 5 \mathrm{t} \mathrm{ha}^{-1}$ with 50mM sea water, $\mathrm{T}_{6}=$ Compost @ $10 \mathrm{t} \mathrm{ha}^{-1}$ with $50 \mathrm{mM}$ sea water, $\mathrm{T}_{7}=$ Compost @ $5 \mathrm{t} \mathrm{ha}^{-1}$ with $100 \mathrm{mM}$ sea water, $\mathrm{T}_{8}=$ Compost @ $10 \mathrm{t} \mathrm{ha}^{-1}$ with 100mM sea water, $\mathrm{T}_{9}=$ Biochar @ $5 \mathrm{t} \mathrm{ha}^{-1}, \mathrm{~T}_{10}=$ Biochar @ $10 \mathrm{t} \mathrm{ha}^{-1}, \mathrm{~T}_{11}=$ Biochar @ $5 \mathrm{t}$ ha $^{-1}$ with $50 \mathrm{mM}$ sea water, $\mathrm{T}_{12}=$ Biochar @ $10 \mathrm{t} \mathrm{ha}^{-1}$ with $50 \mathrm{mM}$ sea water, $\mathrm{T}_{13}=$ Biochar @ $5 \mathrm{t} \mathrm{ha}^{-1}$ with $100 \mathrm{mM}$ sea water, $\mathrm{T}_{14}=$ Biochar @ $10 \mathrm{t} \mathrm{ha}^{-1}$ with $100 \mathrm{mM}$ sea water

\section{Yield and yield contributing characters}

\section{Number of pods plant ${ }^{-1}$}

Soybean plants exposed to salinity caused a significant reduction in number of pod plant ${ }^{-1}$ (Table 1). Organic amendments with water hyacinth compost and rice husk biochar increased pods plant ${ }^{-1}$ at $50 \mathrm{mM}$ and $100 \mathrm{mM}$ salinity stress. The lowest number of pod plant ${ }^{-1}$ was found at $10 \mathrm{dSm}^{-1}$ salinity level (16). But due to organic amendment, the number of pod plant ${ }^{-1}$ was increased as compare to the control. Highest number of pods plant ${ }^{-1}(51)$ was observed when biochar was added @ $5 \mathrm{t} \mathrm{ha}^{-1}$ and the lowest (33.67) @ $10 \mathrm{t} \mathrm{ha} \mathrm{a}^{-1}$ under control condition. At 5 $\mathrm{dSm}^{-1}$ salinity condition, highest number of pods plant ${ }^{-1}$ (35.33) was obtained from biochar @ 5 $\mathrm{t} \mathrm{ha} \mathrm{a}^{-1}$ and lowest (27.67) by applying compost @ $5 \mathrm{t} \mathrm{ha}^{-1}$. Under $10 \mathrm{dSm}^{-1}$ salinity condition, highest number of podplant ${ }^{-1}$ (22.67) was obtained when soil was treated with compost @ $5 \mathrm{t} \mathrm{ha}$ 1 and the lowest (20.33) was recorded when biochar as well as compost added @ $10 \mathrm{t} \mathrm{ha}^{-1}$. Similar result was found by Leithy et al. (2010) on peanut at different levels of salinity.

\section{Number of seed pod $^{-1}$}

The number of seed pod $^{-1}$ also reduced by salinity stress in soybean (Table 1). This reduction rate was increasing with the increasing salinity stress. Application of compost and biochar (5 and $10 \mathrm{t} \mathrm{ha}^{-1}$ ) significantly increased the number of seeds pod ${ }^{-1}$ in soybean at 0,5 and $10 \mathrm{dSm}^{-1}$ salinity level. The lowest number of seeds $\operatorname{pod}^{-1}(0.8)$ was observed at $10 \mathrm{dSm}^{-1}$ salinity level. But due to addition of organic amendment, the number of seeds pod $^{-1}$ was increased compared to control. The highest number of seeds pod $^{-1}(2.17)$ was observed when biochar was added @ $5 \mathrm{t}$ $\mathrm{ha}^{-1}$ and the lowest (1.84) when compost added @ $10 \mathrm{t} \mathrm{ha}^{-1}$. At $5 \mathrm{dSm}^{-1}$ salinity condition, highest number of seeds pod ${ }^{-1}(1.80)$ was obtained from biochar @ $5 \mathrm{t} \mathrm{ha}^{-1}$ and lowest (1.27) at @ $10 \mathrm{t} \mathrm{ha}^{-1}$. Under $10 \mathrm{dSm}^{-1}$ saline condition, highest number of seed $\operatorname{pod}^{-1}(1.31)$ was obtained when soil was treated with biochar @ $5 \mathrm{t} \mathrm{ha}^{-1}$ and it was lowest (1.05) when compost was added 
in the soil @ $10 \mathrm{t} \mathrm{ha}^{-1}$. Similar result was also found by Leithy et al. (2010) on peanut at different levels of salinity.

\section{0-seed weight}

Salt stress caused a significant decrease in 100- seed weight of soybean plant (Table1). Organic amendments with both compost and biochar significantly increased the 100-seed weight of soybean at 0,5 and $10 \mathrm{dSm}^{-1}$ salinity stress conditions. Highest 100 -seed weight $(14.9 \mathrm{~g})$ was observed when biochar was added @ $5 \mathrm{t} \mathrm{ha}^{-1}$ and the lowest 100 -seed weight (13.86 g) when compost was added @ 5t ha ${ }^{-1}$ under control condition. At $5 \mathrm{dSm}^{-1} 0 \mathrm{mM}$ salinity condition, highest 100-seed weight (12.40 g) was obtained from biochar@ $5 \mathrm{t} \mathrm{ha}^{-1}$ and lowest 100-seed weight (11.20 g) when compost was applied @ $5 \mathrm{t} \mathrm{ha}^{-1}$. Under $10 \mathrm{dSm}^{-1}$ saline condition, highest 100- seed weight (11.2) was obtained when soil was treated with compost @ $5 \mathrm{t} \mathrm{ha}^{-1}$ and it was lowest (9.67) when biochar was added in the soil @ $5 \mathrm{t} \mathrm{ha}^{-1}$.

\section{Seed yield}

Salt stress caused a significant decrease in yield of soybean plant (Table1). Organic amendments with both compost and biochar significantly increased the yield of soybean at 0,50 and $100 \mathrm{mM}$ salinity stress conditions. Under $5 \mathrm{dSm}^{-1}$ salinity stress, both compost and biochar also showed a considerable yield in soybean plant.

Table 1. Effect of organic amendments on yield and yield contributing characters of soybean under saline condition

\begin{tabular}{lcccc}
\hline Treatments & $\begin{array}{c}\text { No. of pods } \\
\text { plant }^{-1}\end{array}$ & $\begin{array}{c}\text { No. of seeds } \\
\text { pod }^{-1}\end{array}$ & $\begin{array}{c}\text { 100- seed } \\
\text { weight }(\mathrm{g})\end{array}$ & $\begin{array}{c}\text { Seed yield } \\
\left.\text { (g plant }^{-1}\right)\end{array}$ \\
\hline $\mathrm{T}_{0}$ & 33.33 & 1.43 & 13.10 & 6.18 \\
$\mathrm{~T}_{1}$ & 25.00 & 1.17 & 10.40 & 2.94 \\
$\mathrm{~T}_{2}$ & 16.00 & 0.80 & 8.90 & 1.16 \\
$\mathrm{~T}_{3}$ & 37.00 & 1.96 & 13.90 & 11.42 \\
$\mathrm{~T}_{4}$ & 33.67 & 1.84 & 14.30 & 9.41 \\
$\mathrm{~T}_{5}$ & 27.67 & 1.40 & 11.20 & 4.79 \\
$\mathrm{~T}_{6}$ & 32.00 & 1.27 & 12.20 & 4.87 \\
$\mathrm{~T}_{7}$ & 22.67 & 1.17 & 11.20 & 2.95 \\
$\mathrm{~T}_{8}$ & 20.33 & 1.05 & 10.40 & 2.19 \\
$\mathrm{~T}_{9}$ & 51.00 & 2.17 & 14.90 & 15.65 \\
$\mathrm{~T}_{10}$ & 46.00 & 2.02 & 14.50 & 13.33 \\
$\mathrm{~T}_{11}$ & 35.33 & 1.80 & 12.40 & 8.63 \\
$\mathrm{~T}_{12}$ & 32.33 & 1.71 & 12.10 & 7.54 \\
$\mathrm{~T}_{13}$ & 21.67 & 1.31 & 9.70 & 2.74 \\
$\mathrm{~T}_{14}$ & 20.33 & 1.17 & 10.30 & 2.61 \\
\hline $\mathrm{LSD}(0.05)$ & 3.92 & 0.20 & 0.68 & 2.15 \\
$\mathrm{CV}(\%)$ & 7.80 & 8.20 & 3.40 & 20.10 \\
\hline
\end{tabular}

$\mathrm{T}_{0}=$ Control (without organic amendments and sea water), $\mathrm{T}_{1}=5 \mathrm{dSm}^{-1}$ sea- water $\mathrm{T}_{2}=10 \mathrm{dSm}^{-1}$ sea- water, $\mathrm{T}_{3}=$ Compost @ $5 \mathrm{t} \mathrm{ha}^{-1}, \mathrm{~T}_{4}=$ Compost @ $10 \mathrm{t} \mathrm{ha}^{-1}, \mathrm{~T}_{5}=$ Compost @ $5 \mathrm{t} \mathrm{ha}^{-1}$ with $5 \mathrm{dSm}^{-1}$ seawater, $\mathrm{T}_{6}=$ Compost@10 tha ${ }^{-1}$ with $5 \mathrm{dSm}^{-1}$ seawater, T7= Compost @ $5 \mathrm{t} \mathrm{ha}^{-1}$ with $10 \mathrm{dSm}^{-1}$ seawater, T8= Compost @ $10 \mathrm{t} \mathrm{ha}^{-1}$ with $10 \mathrm{dSm}{ }^{-1}$ seawater, T9=Biochar @ $5 \mathrm{t} \mathrm{ha}^{-1}, \mathrm{~T}_{10}=$ Biochar @ $10 \mathrm{t} \mathrm{ha}^{-1}, \mathrm{~T}_{11}=$ Biochar@ $5 \mathrm{t}$ ha ${ }^{-1}$ with $5 \mathrm{dSm}^{-1}$ seawater, $\mathrm{T}_{12}=$ Biochar @ $10 \mathrm{t} \mathrm{ha}^{-1}$ with $5 \mathrm{dSm}^{-1}$ sea- water, $\mathrm{T}_{13}=$ Biochar @ $5 \mathrm{t} \mathrm{ha}^{-1}$ with $10 \mathrm{dSm}^{-1}$ sea- water, $\mathrm{T}_{14}=$ Biochar @ $10 \mathrm{t} \mathrm{ha}^{-1}$ with $10 \mathrm{dSm}^{-1}$ sea-water

At $5 \mathrm{dSm}^{-1}$ salinity stress yield was higher at $10 \mathrm{t} \mathrm{ha}^{-1}$ than $5 \mathrm{t} \mathrm{ha}^{-1}$ compost treatments but at 10 $\mathrm{dSm}^{-1}$ salt level the increment of yield occurred at $5 \mathrm{t} \mathrm{ha}^{-1}$ compost treatment. In case of biochar, at 0,5 and $10 \mathrm{dSm}^{-1}$ salt condition yield was higher at $5 \mathrm{tha}^{-1}$ than $10 \mathrm{t} \mathrm{ha}^{-1}$. Highest seed yield (15.65 $\left.\mathrm{g} \mathrm{plant}^{-1}\right)$ was observed when biochar was added @ $5 \mathrm{t} \mathrm{ha}^{-1}$ and the lowest $\left(9.41 \mathrm{~g} \mathrm{plant}^{-1}\right)$ yield when compost was added @ $10 \mathrm{t} \mathrm{ha}^{-1}$ under control condition. At $5 \mathrm{dSm}^{-1}$ salinity condition, highest seed yield (8.63 g plant $\left.{ }^{-1}\right)$ was obtained from biochar @ $5 \mathrm{t} \mathrm{ha}^{-1}$ and the lowest seed yield (4.79 $\mathrm{g} \mathrm{plant}^{-1}$ ) when compost was applied @ $5 \mathrm{t} \mathrm{ha}^{-1}$. Under $10 \mathrm{dSm}^{-1}$ saline condition, highest 
seed yield (2.95 g plant $\left.{ }^{-1}\right)$ was obtained when soil was treated with compost @ $5 \mathrm{t} \mathrm{ha}^{-1}$ and lowest $\left(2.19 \mathrm{~g} \mathrm{plant}^{-1}\right)$ when compost added in the soil @ $10 \mathrm{tha}^{-1}$.

\section{Conclusion}

From the results it may be concluded that salinity decreased plant height, leaf, stem, root dry matter and yield contributing parameters of soybean plant. Application of water hyacinth compost and rice husk biochar had positive effects on mitigation of negative effects of salinity stress on soybean growth and yield. However, rice husk biochar at the rate of $5 \mathrm{t} \mathrm{ha}^{-1}$ showed best result to mitigate salinity stress at low salinity $\left(5 \mathrm{dSm}^{-1}\right)$ condition.

\section{References}

Abou El-Magd, M. M., M. F. Zaki and S. D. Abou-Hussein. 2008. Effect of organic manure and different levels of saline irrigation water on growth, green yield and chemical content of sweet fennel. Australian J. Basic and Appl. Sci.2(1): 90-98..

Akhtar, S. S., N. A. Mathias, N. Muhammad, A. Z. Zahirand L. Fulai. 2015. Interactive effect of biochar and plant growth-promoting bacterial endophytes on ameliorating salinity stress in maize. Functio. Plant Biol. 42: 770-781.

Ali, M. A., M. T. Islam and M. T. Islam. 2004. Effect of salinity on some morpho-physiological characters and yield in three sesame cultivars. J. Bangladesh Agric. Univ.3: 209-214.

Asai, H., B. K. Samson, H. M. Stephan, K. Songyi khan gsuthor, K. Homma, Y. Kiyono, Y. Inoue, T. Shiraiwa and T. Horie. 2009. Biochar amendment techniques for upland rice production in Northern Laos 1. Soil physical properties, leaf SPAD and grain yield. Field Crop Res. 111: 81-84.

Bernstein, L. 1975. Effects of salinity and sodicity on plant growth. Annu. Rev. Phytopathol. 13: 295-312.

Chan, K. Y., L. V. Z. wieten, I. Meszaros, A. Downie and S. Joseph. 2008. Using poultry litter biochars as soil amendments. Australalian J. Soil Res. 46:437-444.

Chan, K. Y., L. V. Zwieten, I. Meszaros, A. Downie and S. Joseph. 2007. Agronomic values of green waste biochar as a soil amendment. Australian J. Soil Res. 45:629-634.

Debosz, K., S. B. O. Petersen, L. K. Kure and P. Ambus. 2002. Evaluating effects of sewage sludge and household compost on soil physical, chemical and microbiological properties.Appl. Soil Ec.19: 237-248.

Food and Agricultural Organization (FAO). 2013. Land and Plant Nutrition Management Service. http://www.fao.org/ag/agl/agll/spush.

Gaballah, M. S. and M. S. Mandour. 1999. Increasing drought resistance of wheat plants during grain filling byusing chemical desiccants. J. Sci. Mansoura Univ., 25(2): 833-841.

Gomez, A. A. and A. A. Gomez. 1984. Statistical procedure of agricultural Research. John Wiley and Sons. New York. 20-2015.

Gopal, and K. S. Dube. 2003. Influence of soil and foliar application of potassium on growth, nutrient utilization, yield and quality of sugarcane (Saccharum officinarum L.). New Botanist. 21(1-4): 13-20.

Hussein, M. M., L. K. Balbaa and M. S. Gaballah. 2007. Salicylic acid and salinity effects on growth of maize plants. Res. J.Agric.Biol. Sci. 3(4): 321-328. 
Idrees, S., M. S. Qureshi, M. Y. Ashraf, M. Hussain and N. H. Naveed. 2004. Influence of sulphate of potash (SOP) and farmyard manure (FYM) on sugarcane (Saccharum officinarum L.) grown under salt stress. Pakistan J. Life Social Sci. 2(1): 65-69.

Karim, M. A., M. A. E. Nawata and S. Shigenaga. 1992. Dry matter production and distribution of mineral ions in different parts of plant in hexaploid triticale under salt stress condition. Japanese J. Crop Sci. 61 (3):439-446.

Laird, D. A., P. D. Fleming, D. D. Davis, R. Horton, B. Wang, D. L. Karlen. 2010. Impact of biochar amendments on the quality of a typical Midwestern agricultural soil. Geoderma in press: Geoderma doi:10.1016/j.geoderma.2010.1005.1013.

Leithy, S., M. S. Gaballah and A. M. Gomaa. 2010. Associative impact of bio- and organic fertilizers on geranium plants grown under saline conditions. Electron. J. Environ. Agric. Food Chem. 9(3): 617-626.

Lynch, D. H., R. P. Voroney and P. R. Warman. 2005. Soil physical properties and organic matter fractions under forages receiving composts, manure or fertilizer. Compost Sei. Util.13: 252261.

Raafat, N. Z. and E. E. R. Tharwat. 2011. Improving wheat grain yield and its quality under salinity conditions at a newly reclaimed soil using different organic sources as soil or foliar applications. J. Appl. Sci. Res. 7: 42-55.

Raptan, P. K., Hamid, A., Khaliq, Q. A., A. R. M. Solaiman, A. J. U. Ahmed and M. A. Karim. 2001. Salinity tolerance of balckgram and mungbean: II. Mineral ion accumulation in different plant parts. Korean J. Crop Sci. 46: 380-394.

SRDI. 2010. Saline soils of Bangladesh. SRMAF Project, Ministry of Agriculture, Bangladesh. 1-60.

Stamatiadis, S., M. Werner and M. Buchanan. 1999. Field assessment of soil quality as affected by compost and fertilizer application in a broccoli field (San Benito County, California).Appl. Soil Ecol.1:217-225.

Sultana, N. T., R. Ikeda and H. Itoh. 1999. Effect of salinity on yield attributes and yield inrice genotypes. Environ. Expt. Bot. 42: 211-220.

Tanji, K. K. 1990. Agricultural salinity assessment and management. ASCE manuals and reports on engineering practice (USA).

Tejada, M., C. J. L. Garcia, Gonzalez and M. T. Hernandez. 2006. Use of organic amendment as a strategy for saline soil remediation: Influence on the physical, chemical and biological properties of soil. Soil Bid. Biochem. 38:1413-1421.

Verheijen, F. G. A., S. Jeffery, A. C. Bastos, V. D. Velde and M. I. Diafas. 2009. Biochar application to soils: A critical scientific review of effects on soil properties, processes and functions. Official Publications of the European Communities: Luxembourg. EUR 24099 EN. 61.

Wanas, S.A. and W. M. Omran. 2006. Advantages of Applying Various Compost Types to Different Layers of Sandy Soil: 1. Hydro-Physical Properties. J. Appl. Sci. Res. 2(12): 1298-1303. 